Instructions for Authors: Papers and short notes from contributors anywhere in the world are welcome for consideration for publication in The Lichenologist and may be on any aspect of lichenology. However, priority in publication will be given to those who are members of the British Lichen Society.

Manuscripts must be typewritten on foolscap or A4 size paper in double or treble spacing with 1 inch margins all round and submitted in triplicate to the Senior Editor (Dr D. H. Brown) or (for North America) Professor V. Ahmadjian, Department of Biology, Clark University, Worcester, Mass 01610, USA. Word-processed manuscripts should not use italics (underline appropriate words) or right-hand justification.

Original line illustrations must be in black ink on stiff white card, preferably Bristol board. Copies of all illustrations should also be supplied at the size intended for publication.

As a guide to the layout of synonymy, keys, references, etc., recent issues should be consulted. The spellings of locality names in Britain and abroad must follow those of the most recent editions of maps published by the Ordnance Survey and The Times Atlas of the World, respectively. Titles of periodicals should be given in full (except in taxonomic treatments in text where they should be abbreviated as in the fourth edition of the World List of Scientific Periodicals and its supplements).

Examples of style employed in

(a) description of new species:

Ramalina jamesii Krog sp. nov.

Thallus saxicola, ascendens vel plus minusve inclinatus ...etc.

Typus: Portugal, Madeira, Porto Santo, Pico do Facho, $33^{\circ} 05^{\prime} \mathrm{N}, 16^{\circ} 19^{\prime} \mathrm{W}$, on acidic rock, $350 \mathrm{~m}$ alt, 7 April 1988, H. Krog \& E. Timdal 6163 (O-holotypus; BM, UPS-isotypi).

(b) citation of described species or new combinations:

Pyrenopsis furfurea (Nyl.) Th. Fr.

Bot. Notiser 1866: 58 (1866); type: Scotland, Ben Lawers, 1864, fones (H-NYL 42916-lectotype; BM-isolectotype).

Pyrenopsidium terrigenum (Th. Fr.) Forss., Nova Acta R. Soc. Scient. Upsal., ser. 3, 13(6): 81 (1985).Pyrenopsis haematopsis (Sommerf.) B. terrigena Th. Fr. in Hellbom, Öfvers K. Vetens Akad. Forh. 22(6): 478 (1865); type: Sweden, Lule Lappmark, Skarfi, 1864, Hellbom (UPS - holotype).

(c) citation of specimens examined:

Selected specimens examined: U.K.: Scotland: Easterness: Abernethy Forest, near Forest Lodge, 38/01.16, on Pimus lignum, 1975, Coppins [2199] \& Rose (BM, E).-Germany: Bayern: Allgauer Alpen, 1957, Schoppel \& Poelt [Poelt, Lichenes Alpinum no. 56] (H).-Australia: Tasmania: Weindorfers Forest, $41^{\circ} 38^{\prime} \mathrm{S}, 145^{\circ} 56^{\prime} \mathrm{E}, 920 \mathrm{~m}, 6$ March 1988, Kantvilas $68 / 88$ (E); Cox Bight, behind west beach, sealevel, 5 March 1985, f. A. Elix 20945 (ANUC). Victoria: Bellel Creek, c. 1800m, 5 June 1983, M. E. Hale (HO).

(d) citation of references in the text:

Green \& White (1988) or (Brown et al. 1988a, b, 1989; Smith \& Jones 1990)

(e) citation of references:

Culberson, C. F. \& Kristinsson, H. (1970a) A standardized method for the identification of lichen products. Fournal of Chromatography 46: 85-93.

Hale, M. E. (1983) The Biology of Lichens. 3rd Edn. London: Arnold.

Hawksworth, D. L. (1976) Lichen chemotaxonomy. In Lichenology: Progress and Problems (D. H. Brown, D. L. Hawksworth \& R. H. Bailey, eds): 139-184. London: Academic Press.

List in alphabetic sequence with: single authors, by date; two authors, alphabetically, then by date; three or more authors by date only.

Copyright/Offprints. Authors submitting a manuscript do so on the understanding that if it is accepted for publication, copyright in the paper for the United States of America shall be assigned to the Society. In consideration for the assignment of copyright, the Society will supply 50 offprints of each paper or Short Communication but not of Book Reviews. Further offprints may be ordered at extra cost at the proof stage. The Society will not put any limitation on the personal freedom of the author to use material contained in the paper in other works which may be published in North America or elsewhere. Reprints must be ordered directly from Academic Press Inc. when the author returns the proofs of his article.

Page charges are not levied, but if funds to cover printing costs are available quicker publication, or that of unusually long papers, can be facilitated.

Books dealing with any aspect of lichenology will be reviewed. Publishers wishing to have works reviewed in The Lichenologist should send them to Dr B. J. Coppins, Royal Botanic Gardens, Inverleith Row, Edinburgh, EH3 $5 \mathrm{LR}$, in the first instance.

This journal is covered by Current Contents and Biological Abstracts.

Notice: While the Senior Editor and Editors endeavour to check the accuracy of statements in contributions in as far as they are able, it should be emphasized that views expressed in papers in The Lichenologist are those of their authors and do not necessarily represent those of the British Lichen Society, Academic Press Ltd, the Senior Editor, or the Editors.

(9) 1992 British Lichen Society. The appearance of the code at the bottom of the first page of a paper in this journal indicates the copyright owner's consent that copies of the paper may be made for personal or internal use, or for the personal or internal use of specific clients in the USA. This consent is given on the condition, within the USA, that the copier pay the stated per copy fee through the Copyright Clearance Center, Inc., 27 Congress Street, Salem, MA 01970, for copying beyond that permitted by Sections 107 or 108 of the US Copyright Law. This consent does not extend to other kinds of copying, such as copying for general distribution, for advertising or promotional purposes, for creating new collective works, for copying or distributing copies outside the USA. 


\section{THE LICHENOLOGIST}

Vol. 24. Part 4

LAUNDON, Jack R.-Lepraria in the British Isles

Coppins, B. J., JAMES, P. W. and HAwKsworth, D. L.-New species and combinations in The Lichen Flora of Great Britain and Ireland

DIEDERICH, Paul-Stromatopogon baldwinii Zahlbr., a lichenicolous coelomycete with dimorphic conidia

GreENFIELD, L. G.-Nitrogen analyses of New Zealand and Antarctic lichens

LEUCKERT, Ch. and KNOPH, J.-G.-European taxa of saxicolous Lecidella containing chloroxanthones: identification of patterns using thin layer chromatography

HeNDERSON, A.-Literature on air pollution and lichens XXXVI

SHORT COMMUNICATIONS

JøRGENSEN, P. M. and GALloway, D. J.-Notes on Candelaria crawfordii

The Lichenologist, Vol. 24, Part 3 was published on 12 August 1992

Published four times a year for the British Lichen Society by Academic Press Limited, 24-28 Oval Road, London NW 1 7DX, England

Free to full members of the British Lichen Society

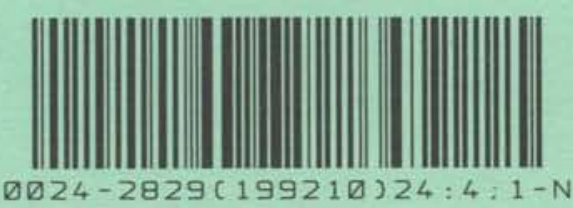

